\title{
The Essence of the Fundamental Right to Equal Treatment: Back to the Origins
}

\author{
Elise Muir ${ }^{*}$
}

(Received 01 May 2019; accepted 30 May 2019)

\begin{abstract}
The principle of equal treatment is essential to the process of European integration. It is one of the main principles - if not the main principle - driving this process forward. Equal treatment between States and the prohibition to discriminate on grounds of nationality are indeed cornerstones of the European project. Furthermore, the principle of equal treatment is a fundamental right according to which comparable situations must not be treated differently, and that different situations must not be treated in the same way unless such treatment is objectively justified. This fundamental right has also been given more specific expression in a set of Treaty provisions and Directives prohibiting discrimination on grounds of sex, racial or ethnic origin, religion or belief, disability, age, or sexual orientation. Precisely because the principle of equal treatment performs several important functions in the EU legal order, it is shaped by several sets of actors: constituent powers, legislature and judiciary. The article first maps out the various functions that the principle of equal treatment fulfills in EU law, placing emphasis on the complexity of the relevant constitutional framework. This sets the floor for a critical discussion on how different institutional visions of the principle may compete, and a reflection of the role of the concept of 'essence' to articulate these competing visions.
\end{abstract}

Keywords: Essence; equal treatment; non-discrimination; fundamental rights

\section{A. Introduction: The Principle of Equal Treatment is Essential to the EU Integration Process}

The principle of equality or non-discrimination ${ }^{1}$ constitutes one of the cornerstones of the process of European integration. The pursuit of equality among the people and states is a primary objective. $^{2}$ This has long been perceived as a precondition to progressing towards "an ever closer union among the peoples of Europe" 3 - to the extent that the Union is actually "founded" on the value of equality. ${ }^{4}$ References to equality are very diverse. ${ }^{5}$ Yet, they all find a common origin in a

${ }^{*}$ Prof. Dr. Elise Muir is head of the Institute for European Law of the KU Leuven and visiting professor at the College of Europe. This paper elaborates on a conceptual framework first published in Elise Muir, EU Equality Law: The First Fundamental Rights Policy of the EU (Oxford Univ. Press 2018).

${ }^{1}$ In this paper, as is often the case in the Court's case law, these notions are used interchangeably.

${ }^{2}$ See Consolidated Version of the Treaty on European Union arts. 3(3), 4(2), Oct. 26, 2012, 2012 O.J. (C 326) 01 [hereinafter TEU]; see also Consolidated Version of the Treaty on the Functioning of the European Union art. 8, Oct. 26, 2012, 2012 O.J. (C 326) 47 [hereinafter TFEU].

${ }^{3}$ TEU art. 1.

${ }^{4}$ See TEU art. 2 .

${ }^{5}$ See generally Sophia Koukoulis-Spiliotpoulos, The Amended Equal Treatment Directive (2002/73): An Expression of Constitutional Principles / Fundamental Rights, 12 MAASTRICHT J. EuR. \& COMP. L. 327, 331-32 (2005) (discussing the exploration of different expressions on the principle of equal treatment); TAKIS TRIDIMAS, GENERAL PRINCIPLES OF EU LAW 60 (2nd ed., Oxford Univ. Press 2006).

(C) 2019 The Author. Published by Cambridge University Press on behalf of the German Law Journal. This is an Open Access article, distributed under the terms of the Creative Commons Attribution licence (http://creativecommons.org/licenses/by/4.0/), which permits unrestricted re-use, distribution, and reproduction in any medium, provided the original work is properly cited. 
"meta-principle of equality" defined by reference to the Aristotelian formula adjusted in the context of EU law: Compliance with the principle of equal treatment requires that comparable situations must not be treated differently, and that different situations must not be treated in the same way unless such treatment is objectively justified. ${ }^{6}$ It will be referred to hereafter as the "standard formula."

The right to equal treatment therefore has a long history as well as a prominent role in EU law. This right is also very dynamic: Its modes of expression and functions have significantly evolved over the past two decades. After multiple decades of existence as a non-written principle and in selected provisions of the EU Treaties, the general principle of equal treatment has been enshrined in several written provisions of the Charter of Fundamental Rights of the European Union ("CFEU" or "Charter"). This strong constitutional anchorage now provides the judiciary with a clearer mandate to enforce the right to equal treatment. The narrative of equal treatment has also been intensely politicized. The insertion of Article 13 in the Treaty establishing the European Community by the Treaty of Amsterdam — now Article 19 TFEU-has allowed for the adoption of directives intended to give expression to the fundamental right to equal treatment in specific settings. This legislation gives political visibility, as well as legitimacy, to approaches to equal treatment that may differ from the approach developed through judicial interpretation of the principle of equal treatment enshrined in EU constitutional law. Such legislative tools therefore add to the diversity of modes of expression of the right to equal treatment and its functions in EU law.

What is the role of the concept of "essence" of fundamental rights, as provided for in Article 52(1) CFEU, to articulate the analysis of limitations to Charter rights in relation to this multifaceted, ancient, and yet dynamic right to equal treatment? The central idea behind the fundamental right to equal treatment remains enshrined in the standard formula that defines the principle of equal treatment. According to the formula, quoted above, an analysis of a restriction to equal treatment calls for a balancing act. The idea of a hard core of fundamental rights that could not suffer any restrictions, as defended by the supporters of an absolute reading of the concept of "essence of fundamental rights," is therefore incompatible with the architecture of the principle of equal treatment encapsulated in the standard formula. As will be shown, arguments related to the possible breach of the fundamental right to equal treatment largely continue to be processed through the lens of that formula. Equal treatment provisions in the Charter are most often treated as comforting the age-old approach developed on the basis of the corresponding general principle of EU law. As a consequence, Article 52(1) CFEU is functionally redundant for the analysis of restrictions to the fundamental right to equal treatment, and the concept of "essence" can simply be subsumed in the traditional proportionality test.

If the coexistence of several sources for the protection of equal treatment has not fundamentally changed the approach for the analysis of restrictions to that right, it will be argued that such a coexistence places the Court of Justice of the European Union (the "Court" or "CJEU") in an increasingly delicate situation to select the appropriate legal framework. Indeed, the various manifestations of the principle of equal treatment at constitutional and legislative levels each fulfil different functions. Expressions of the principle of equal treatment at the constitutional level may act as a traditional constitutional benchmark, which will be discussed in Section B; others enable the legislature to further elaborate on the scope and content of the right, which will be discussed in Section C. The very existence of legislation giving expression to the fundamental right to equal treatment calls for rigor in the analysis of the corresponding constitutional version of the right in order to avoid confusion between the two layers of norms.

\footnotetext{
${ }^{6}$ See Joined Cases 117/76 \& 16/77, Albert Ruckdeschel \& Co. and Hansa Lagerhaus Ströh \& Co. v. Hauptzollamt HamburgSt. Annen; Diamalt AG v. Hauptzollamt Itzehoe, 1977 E.C.R. 1753, para. 7 (the first limb of this formula is the most classic expression of the principle, but the second limb is also of practical relevance); see also Case C-149/10, Zoi Chatzi v. Ypourgos Oikonomikon, 2010 E.C.R. I-8489, paras. 68-75.

${ }^{7}$ As further elaborated upon in the introductory contribution of this Special Issue.
} 
For instance, the constitutional version of the right of equal treatment may constitute the applicable benchmark to assess a situation related to differential treatment against same-sex couples without, however, the Directive that prohibits discrimination on sexual orientation in employment ${ }^{8}$ being applicable. ${ }^{9}$ In such settings, the coexistence of several sources, including legislative guidance on the content of the fundamental right that is not applicable per se, makes the task of the Court delicate. The choice of a model to analyze restrictions to the fundamental right to equal treatment crystallizes the related uncertainties. As a consequence, and understandably, the Court has increasingly relied on the analytical framework spelled out in the Charter. This allows the Court to rely on a written norm that has constitutional status. At first sight, it offers a more solid ground than general principles to support an approach that cannot be based on legislation. In that context, however, the concept of "essence" enshrined in Article 52(1) CFEU to examine limitations to Charter rights has so far been a source of confusion rather than clarity, as will be discussed in Section D.

The main constitutional and legislative sources for the protection of the right to equal treatment are introduced in the next two sections. This sets the floor for the subsequent examination of the interplay between these sources in the recent case law of the Court on the "essence" of the fundamental right to equal treatment.

\section{B. Equal Treatment: A Principle with Multiple Manifestations at the Constitutional Level}

EU constitutional law, understood to include the Treaties, the Charter, as well as general principles of EU law, includes several references to equal treatment. These references to equal treatment complement and interact with one another. They can best be introduced by reference to the function that they perform in the EU legal order. The first category of instruments is a classic expression of a fundamental right at the constitutional level in so far as they are intended to protect individuals against arbitrariness. A second category of tools acts both as a constitutional benchmark within the meaning just described and as a regulatory tool; they may indeed constitute the expression and exercise of an EU competence. It will be explained that when both categories of provisions coexist, those with a dual function will be used as the point of reference and Article 52(1) CFEU will not be relevant for the analysis of restrictions; the principle of equal treatment understood as a mere constitutional benchmark therefore acts as a default point of reference.

The importance of distinguishing between the various types and functions of provisions giving expression to the principle of equal treatment is twofold. On the one hand, the concept of "essence" of fundamental rights enshrined in Article 52(1) CFEU is only formally relevant for the analysis of rights protected in the Charter as such, in contrast to norms protected in the form of general principles and Treaty provisions. On the other hand, as already noted and as will be further explored in Section $\mathrm{D}$, the coexistence of competing versions of the right each performing a different function may place the Court in a difficult situation to decide on the appropriate analytical model.

\section{The Prohibition of Discrimination as a Constitutional Benchmark}

Like other fundamental rights, the prohibition of discrimination is protected through a combination of unwritten (1) and written (2) constitutional tools. Both largely perform a comparable function in the EU legal system (3).

\footnotetext{
${ }^{8}$ See Council Directive 2000/78, arts. 2, 16, 2000 O.J. (L 303) (EC) (which established a general framework for equal treatment in employment and occupation).

${ }^{9}$ See generally Case C-528/13 Geoffrey Léger v. Ministre des Affaires sociales, de la Santé et des Droits des femmes and Etablissement français du sang, (Apr. 29, 2015), http://curia.europa.eu/ (for instance, if the situation does not relate to employment); see also Section D(II) below.
} 


\section{The General Principle of Equality}

The initial European Economic Treaty did not provide for a specific system for the protection of individuals' rights against arbitrariness from the European institutions or Member States acting within the scope of European law. Yet, the Court filled that lacuna by asserting that fundamental rights form an integral part of the general principles of Union law whose observance the Court ensures ${ }^{10}$ as is clear today from Article 6(3) TEU. This unwritten source of protection is inspired by the constitutional traditions common to the Member States. ${ }^{11}$ International treaties for the protection of human rights on which the Member States have collaborated, or of which they are signatories, can also "supply guidelines to be followed" within EU law. ${ }^{12}$ In that respect, the European Convention for Human Rights ("ECHR"), and in particular its Article 14prohibition of discrimination in the enjoyment of the rights and freedoms set forth in the Convention-and Protocol 12-general prohibition of discrimination-play a specific role. ${ }^{13}$ A recent attempt at implementing the EU's duty to access the ECHR by virtue of Article 6(2) TEU having failed, ${ }^{14}$ the status of the law of the ECHR in the EU remains unchanged to date. ${ }^{15}$

The general principle of equality is one of the fundamental principles of EU law. According to an early statement from the Court in the context of the common agricultural policy, the principle of equality requires that similar situations shall not be treated differently unless differentiation is objectively justified. ${ }^{16}$ More specifically, the Court has further stated that "there can be no doubt that the elimination of discrimination based on sex forms part of . . f fundamental rights," the observance of which the Court must ensure. ${ }^{17}$ The prohibition of age discrimination must also be regarded as a general principle of EU law, ${ }^{18}$ as does the prohibition of discrimination on grounds of religion or belief. ${ }^{19}$ In other words, the prohibition of discrimination on specific grounds such as sex, age, religion, or belief seems to constitute mere expressions of the principle of equal treatment, ${ }^{20}$ all deserving constitutional protection.

\section{Equality in the Charter of Fundamental Rights of the European Union}

The general principle of equal treatment now coexists with the CFEU, which has the same legal value as the Treaties. ${ }^{21}$ The Charter contains an entire title devoted to "Equality," which includes several manifestations of the principle. To start with, Article 20 CFEU states that everyone is equal

\footnotetext{
${ }^{10}$ See Case 11/70, Internationale Handelsgesellschaft mbH v. Einfuhr- und Vorratsstelle für Getreide und Futtermittel, 1970 E.C.R. 1125, para. 4 (the formula was repeated on numerous occasions after this case and extended to apply as a benchmark, not only against EU institutions, but also against Member States acting within the scope of Union law); see also Case C-260/89, Elliniki Radiophonia Tiléorassi AE and Panellinia Omospondia Syllogon Prossopikou v. Dimotiki Etairia Pliroforissis and others, 1991 E.C.R. I-2925, para. 42.

${ }^{11} \mathrm{See}$ Case 4/73, J. Nold, Kohlen- und Baustoffgroßhandlung v. Commission of the European Communities, 1974 E.C.R. 491, para. 13 (which correlates with TEU art. 6(3)).

${ }^{12} I d$.

${ }^{13}$ See id. at para. 12 .

${ }^{14}$ See Case C-2/13, Accession of the European Union to the European Convention for the Protection of Human Rights and Fundamental Freedoms, (Dec. 18, 2014), http://curia.europa.eu/.

${ }^{15}$ See Case C-601/15, J.N. v. Staatssecretaris van Veiligheid en Justitie, paras. 45-46 (Feb. 15, 2016), http://curia.europa.eu/.

${ }^{16}$ See Ruckdeschel \& Co., Joined Cases $117 / 76$ \& 16/77 at para. 7.

${ }^{17}$ Case 149/77, Gabrielle Defrenne v. Société anonyme belge de navigation aérienne Sabena, 1978 E.C.R. 1365, para. 27.

${ }^{18}$ See Case C-144/04, Werner Mangold v. Rüdiger Helm, 2005 E.C.R. I-9981, para. 75.

${ }^{19}$ See Case C-414/16, Vera Egenberger v. Evangelisches Werk für Diakonie und Entwicklung e.V., para. 76 (Apr. 17, 2018), http://curia.europa.eu/.

${ }^{20}$ See Mangold, Case C-144/04 at para. 76 (note that, to date, the Court has carefully avoided referring to a possible general principle prohibiting discrimination on grounds of sexual orientation). See also Case C-267/06, Tadao Maruko v. Versorgungsanstalt der deutschen Bühnen, 2008 E.C.R. I-1757. See generally Case C-147/08, Jürgen Römer v. Freie und Hansestadt Hamburg, 2011 E.C.R. I-3591; Case C-267/12, Frédéric Hay v. Crédit Agricole Mutuel de Charente-Maritime et des Deux-Sèvres (Dec. 12, 2013), http://curia.europa.eu/.

${ }^{21}$ See TEU art. 6(1).
} 
before the law and thus acts as an "umbrella" function in a similar way to the broad version of the general principle of equal treatment.

The equality before the law clause is complemented by three more specific expressions of the principle of equality. First, Article 21(1) CFEU provides for an open-ended list of prohibited grounds of discrimination including sex, race or ethnic origin, religion or belief, age, sexual orientation, and disability on which the EU may also enact legislation by virtue of Article 19 TFEU, as well as Article 157 TFEU. Yet, Article 21(1) CFEU also covers other grounds than those included in specific legal bases-color, social origin, genetic features, language, political or any other opinion, membership of a national minority, property, and birth-and is not exhaustive.

Second, Article 21(2) CFEU duplicates Article 18(1) TFEU ${ }^{22}$ and specifies that discrimination on the ground of nationality is subject to a specific legal regime in so far as it is only prohibited "within the scope of application of the Treaties and without prejudice to any of their specific provisions." The prohibition of discrimination enshrined in EU law has so far indeed been understood as only being applicable to EU citizens ${ }^{23}$ in cross-border situations, and as regards a specific set of circumstances. ${ }^{24}$ The drafters of the Charter wanted to prevent the Charter from being used to extend the scope of the relevant Treaty rules. ${ }^{25}$

Third, Article 23 CFEU is specifically devoted to equality between women and men in all areas, including employment, work, and pay. This Article is partly redundant in the light of Article 21(1) CFEU, which also includes non-discrimination on grounds of sex. Nevertheless, the wording in terms of "equality" instead of "non-discrimination" 26 and the proviso on positive action act as a vivid reminder of the long history of case law and legislative developments in the field of sex equality in employment, work, and pay.

\section{The Function of Classic Constitutional Benchmark and Its Implication}

The core function of the principle of equality, protected as a general principle of EU law and through the Charter, is to act as a traditional fundamental right. It primarily provides a benchmark for judicial review and serves as a source of inspiration for the dynamic interpretation of lower instruments. The system of fundamental rights protection thereby established applies within the EU legal order to "the institutions, bodies, offices and agencies of the Union," 27 and to the Member States when they act within the scope of Union law. ${ }^{28}$ The applicability of EU law entails the applicability of the fundamental rights guaranteed by general principles of either EU law, the Charter, or both. In contrast, where a situation does not fall within the scope of EU law, the Court does not have jurisdiction and EU fundamental rights cannot, in and of themselves, form the basis for such jurisdiction. ${ }^{29}$ It shall be noted that the Court has recently found that the general principle of equal

\footnotetext{
${ }^{22}$ TFEU art. 18(1) has been present since the origins in the form of the Treaty Establishing the European Economic Community art. 7(1), Mar. 25, 1957, 1957 J.O. (C 224) [hereinafter TEEC].

${ }^{23}$ And third country nationals in very specific circumstances-family members or posted workers.

${ }^{24}$ See Case C-452/15, Andrei Petrov, Fedor Biryukov, \& Alexander Sotnichenko v. European Parliament, paras. 38-40 (Nov. 20, 2017), http://curia.europa.eu/. See also Case C-618/15, Udo Voigt v. European Parliament, paras. 80-81 (Nov. 20, 2017), http://curia.europa.eu/.

${ }^{25}$ Although, this may be redundant with TEU art. 6(1), recital 2, and Charter of Fundamental Rights of the European Union art. 51(2), Dec. 18, 2000, 2000 O.J. (C 364) 1 [hereinafter CFEU].

${ }^{26}$ Although we do not do so in this Article, see footnote 1 , specialists in this field often distinguish between equality and non-discrimination-with discrimination being a symptom, and equality a more ambitious aim. See Alexander Somek, $A$ Constitution for Antidiscrimination: Exploring the Vanguard Moment of Community Law, 5 EUR. L.J. 243, 243 (1999). See also Aileen McColgan, Discrimination, Equality and the Law 14-37 (Hart Pub. 2014).

${ }^{27} \mathrm{CFEU}$ art. 51(1).

${ }^{28}$ See Case C-617/10, Åklagaren v. Hans Åkerberg Fransson, para. 19 (Feb. 26, 2013), http://curia.europa.eu/.

${ }^{29}$ See id. at paras. $21-22$.
} 
treatment, ${ }^{30}$ as well as Article $21 \mathrm{CFEU},{ }^{31}$ may be relied upon against private parties acting within the scope of EU law. This recent line of cases has so far always involved a conjunction of legislation bringing the matter within the scope of Union law, and constitutional versions of the same right as that enshrined in the said legislation. We will therefore come back to this in Section C, which is devoted to the fundamental right to equal treatment given expression through legislation. ${ }^{32}$

In terms of its substance, the general principle of equal treatment has traditionally been understood as referring to the standard formula and the related proportionality test. As will be explored further in Section D, the coexistence of expressions of the principle of equal treatment as a general principle of EU law, and of relevant provisions in the Charter, begs the question of the relevance of Article 52(1) CFEU_and the concept of "essence" therein-for rights protected both within the Charter and as general principles. The standard formula, structured around a balancing of interests and developed for the application of the general principle of equal treatment, does not sit comfortably with the absolutist view of an untouchable essence of fundamental rights.

\section{The Prohibition of Discrimination as a Constitutional Benchmark and a Regulatory Tool}

The second category of provisions giving expression to the principle of equal treatment at the constitutional level performs a dual function. These instruments are seen as constitutional benchmarks. In that respect, the function of these Treaty provisions overlaps with both the general principle and the Charter provisions. In addition, these Treaty provisions also act as "regulatory tools" in so far as they define the scope and content of EU intervention in domestic policies. The dual function distinguishes this second source of rights and obligations in the field of nondiscrimination from the other categories of instruments, which only perform one function as examined above.

Such ambivalence is characteristic of the specific nature of the EU legal order. ${ }^{33}$ The normative content of the constitutional charter of the EU performs the function of a constitutional benchmark. Meanwhile, as a "derivative" legal order, ${ }^{34}$ the exercise of EU powers depends upon the allocation of specific competences to the EU so that the EU treaties provide a set of provisions authorizing EU regulatory intervention, and even being constitutive of EU regulatory intervention. The process of European integration has thereby resulted in embedding an atypical amount of normative content in the very same provisions that define the scope for EU regulatory intervention.

The main treaty provisions ${ }^{35}$ performing such dual functions will be briefly introduced before outlining the key implications of the dual nature of their functions for an analysis of the "essence" of the fundamental right to equal treatment.

\footnotetext{
${ }^{30}$ See Mangold, Case C-144/04 at paras. 74-76.

${ }^{31}$ See Egenberger, Case C-414/16 at paras. 76-77.

${ }^{32}$ See generally Joined Cases 569 \& 570/16, Stadt Wuppertal v. Maria Elisabeth Bauer and Volker Willmeroth v. Martina Broßonn, (Nov. 6, 2018), http://curia.europa.eu/ (outlining recent developments in relation to the fundamental right to annual paid leave). See generally Case C-684/16, Max-Planck-Gesellschaft zur Förderung der Wissenschaften e.V. v. Tetsuji Shimizu,(Nov. 6, 2018), http://curia.europa.eu/.

${ }^{33}$ See Tamara K. Hervey, Thirty Years of EU Sex Equality Law: Looking Backwards, Looking Forwards, 12 MAASTRICHT J. EuR. \& COMP. L. 307, 319 (2005) (explaining why Tamara Hervey, for instance, rightly observed in 2005 that EU sex equality law has "contributed to our understanding of the nature of EU law").

${ }^{34}$ See Neil Walker, Human Rights in a Post-National Order: Reconciling Political and Constitutional Pluralism, in SCEPTICAL Essays on Human Rights 129 (Tom Campbell et al. eds., Oxford Univ. Press 2001).

${ }^{35}$ See TRIDIMAS, supra note 5, at 74-135 (outlining a more complete overview of provisions of the EU Treaties including equal treatment clauses).
} 


\section{Treaty Provisions Performing a Dual Function: The Prohibition of Nationality and Sex Discrimination in Relation to Pay ${ }^{36}$}

Two key sets of provisions act both as a constitutional benchmark and a regulatory tool: They relate to the prohibitions of nationality and to a specific aspect of sex discrimination. Article 45(2) TFEU requires the abolition of any discrimination based on nationality between workers of the Member States in view of the worker's right to freedom of movement. ${ }^{37}$ The twins to this Article are the prohibition of restrictions on the freedom of establishment of nationals of a Member State in the territory of another Member State-Article 49(1) TFEU-and the prohibition of restrictions on freedom to provide services in respect of nationals of Member States who are established in a Member State other than that of the person for whom the services are intended-Article 56(1) TFEU.

Read in conjunction, these rules prohibit discrimination on grounds of nationality in relation to employment, establishment, and access and provision of services. For the purpose of this contribution, they can therefore be understood as giving expression to the prohibition of discrimination spelled out in Article 18(1) TFEU. ${ }^{38}$ It may be added that the Treaty provisions on EU citizenship have been read in conjunction with Article 18(1) TFEU to prohibit discrimination on grounds of nationality against certain non-economic actors. ${ }^{39}$ Article 21(1) TFEU, which finds its origins in the Treaty of Maastricht and according to which EU citizens "shall have the right to move and reside freely" within the EU, also complements the prohibition of nationality discrimination to protect non-economic actors. ${ }^{40}$

The second category relates to equal treatment on grounds of sex in relation to pay. This is covered by Article 157(1) TFEU: "Each Member State shall ensure that the principle of equal pay for male and female workers for equal work or work of equal value is applied." Like the Treaty articles on nationality discrimination against economic actors, Article 157(1) TFEU has existed in the Treaty since the origins of the European integration process. ${ }^{41}$ It remains the most prescriptive provision of the Treaty Title on Social Policy. ${ }^{42}$

\section{The Dual Function and its Implications}

These rules have the status of primary law. As such, they cannot be amended through ordinary political processes. Their regulatory effects derive from the fact that said provisions can be forcefully invoked. According to established case law on Articles 49(1), 56(1), and 157(1) TFEU, for instance, they are sufficiently clear, precise, and unconditional to produce direct effect in domestic legal orders. ${ }^{43}$ These provisions can be relied upon not only directly, but also exclusively, before domestic courts. Crucially, they can be relied upon in the absence of any other relevant provisions of EU law, unlike the tools that act as a mere constitutional benchmark because the latter are dependent on the existence of another rule bringing the matter within the scope of EU law. ${ }^{44}$

\footnotetext{
${ }^{36}$ See also Mark Bell, Anti-Discrimination Law and the European Union ch. 1 (Oxford Univ. Press 2002).

${ }^{37}$ See TFEU art. 45(1).

${ }^{38}$ See Catherine Barnard, The Substantive Law of the EU: The Four Freedoms 237-263 (3rd ed., Oxford Univ. Press 2010) (presenting an in-depth and horizontal analysis of these provisions).

${ }^{39}$ See Case C-85/96, María Martínez Sala v. Freistaat Bayern, 1998 E.C.R. I-2691, paras. 62-63.

${ }^{40}$ Case C-413/99, Baumbast and R v. Secretary of State for the Home Department, 2002 E.C.R. I-7091, para. 86.

${ }^{41}$ See TEEC arts. 48, 52, 59, 119.

${ }^{42}$ See Catherine Hoskyns, Integrating Gender: Women, Law and Politics in the European Union 57 (Verso 1996).

${ }^{43}$ See Case C-265/95, Commission of the European Communities v. French Republic, 1974 E.C.R. 6959, para. 41. See also Case C-2/74, Jean Reyners v. Belgian State, 1974 E.C.R. 631, para. 32; Case C-33/74, Johannes Henricus Maria van Binsbergen v. Bestuur van de Bedrijfsvereniging voor de Metaalnijverheid, 1974 E.C.R. 1299, para. 27; Defrenne, Case C-149/77 at para. 39.

${ }^{44}$ See supra Section $\mathrm{B}(\mathrm{I})(3)$.
} 
As a consequence, the jurisdictional interpretation of the provisions performing a dual function clearly influences the scope and content of EU intervention in the field. ${ }^{45}$

An examination of an equal treatment claim based on a provision of EU constitutional law performing a dual function will not necessitate recourse to Article 52(1) CFEU and to the related concept of "essence". Instead, such provisions with a dual function are often given more substance than the rules that act uniquely as constitutional benchmarks. It is commonly accepted that the provisions just mentioned prohibit not only direct, but also indirect discrimination within their respective fields of application. ${ }^{46}$ Furthermore, the implementation of the prohibition of discrimination in the context of all four provisions allows for a partial shift in the burden of proof. In the context of sex equality, by way of example, the Court stated in several cases $^{47}$-and the legislature has confirmed $^{48}$ - that the Member States must ensure, subject to limited exceptions, ${ }^{49}$ that the applicant only needs to establish facts from which it may be presumed that there has been discrimination. The burden of proof is then passed on to the respondent to prove the principle of equal treatment has not been breached. ${ }^{50}$ This makes it easier for applicants to enforce their right to equal treatment on grounds of sex in pay and employment. Although not identical, similar jurisprudential developments relate to the rules on the prohibition of discrimination in the internal market. ${ }^{51}$

\section{Interim Conclusion: The Constitutional Benchmark in Its Bare Version Acts as the Default Option}

The principle of equal treatment is therefore addressed at the constitutional level in EU law in a fragmented way; it is expressed in several branches of EU constitutional law. The coexistence of these various tools may create confusion as to the sources that are best used in different claims, as well as to the relevance of Article 52(1) CFEU and the concept of "essence" therein. One may fear ambiguities in the use of the relevant sources as well as divergent standards of scrutiny. ${ }^{52}$

Yet, as regards these provisions performing a dual function, the overall idea remains fairly simple. If a specific provision that acts both as a constitutional benchmark and a regulatory tool exists and is applicable, it will be used as the relevant legal framework. ${ }^{53}$ This is a natural consequence of the principle according to which the most specific expression of the rule prevails and is confirmed in Article 52(2) CFEU. ${ }^{54}$ Moreover, constitutional benchmarks may only apply within the scope of application of EU law so that it is natural to first look for rules of EU law regulating the field. The

\footnotetext{
${ }^{45}$ See generally Fritz W. Scharpf, The Double Asymmetry of European Integration: Or Why the EU Cannot Be a Social Market Economy (Max Planck Inst. for the Stud. of Soc'y, Working Paper No. 09/12, 2009).

${ }^{46}$ See Case 152/73, Giovanni Maria Sotgiu v. Deutsche Bundespost, 1974 E.C.R. 153, para. 11. See also Case C-237/94, John O’Flynn v. Adjudication Officer, 1996 E.C.R. I-2617, paras. 18-19.

${ }^{47}$ See Case 109/88, Handels- og Kontorfunktionærernes Forbund I Danmark v. Dansk Arbejdsgiverforening, acting on behalf of Danfoss, 1989 E.C.R. 3199, para. 16. See also Case C-127/92, Dr. Pamela Mary Enderby v. Frenchay Health Authority and Secretary of State for Health, 1993 E.C.R. I-5535, para. 14.

${ }^{48}$ See generally Council Directive 97/80, 1998 O.J. (L 14) 6 (EC) (related to the burden of proof in cases of discrimination based on sex).

${ }^{49}$ This does not apply to proceedings in which it is for the court, or competent body, to investigate the facts of the case. Also note that Member States may have rules of evidence which are more favorable to plaintiffs.

${ }^{50}$ See Council Directive, supra note 48 , at art. 4.

${ }^{51}$ See Case C-76/90, Manfred Säger v. Dennemeyer \& Co. Ltd., 1991 E.C.R. I-4221, para. 12. See also Case C-19/92, Dieter Kraus v. Land Baden-Württemberg, 1993 E.C.R. I-1663, para. 32; Case C-55/94, Reinhard Gebhard v. Consiglio dell'Ordine degli Avvocati e Procuratori di Milano, 1995 E.C.R. I-4165, para. 37; Case C-384/93, Alpine Investments BV v. Minister van Financiën, 1995 E.C.R. I-1141, paras. 35, 38; Case C-415/93, Union royale belge des sociétés de football association ASBL and others v. Bosman and others, 1995 E.C.R. I-4921, para. 103.

${ }^{52}$ See Vojtech Belling, Supranational Fundamental Rights or Primacy of Sovereignty? Legal effects of the So-Called Opt-Out from the EU Charter of Fundamental Rights, 18 EUR. L.J. 251, 255 (2012).

${ }^{53}$ See CFEU art. 21, para. 2 (corresponding to the first paragraph of Article 18 of the Treaty on the Functioning of the European Union and which must be applied in compliance with that Article).

${ }^{54}$ See Petrov, Case C-452/15 at paras. $38-40$. See also Voigt, Case C-618/15 at paras. $80-81$.
} 
substance of the principle of equal treatment will then most likely be richer than the plain expression of the general principle of EU law captured in the standard formula or the Charter-or both - version of the right. The high form of protection enshrined in constitutional provisions acting as a benchmark as well as a regulatory tool can precisely be explained by reference to their dual functions. In other words, the regulatory dimension explains the stronger normative content. In such cases, and as noted above, neither Article 52(1) CFEU, nor the concept of "essence" contained therein, will be invoked.

In contrast, in the absence of applicable provisions with a dual function, the constitutional version of the principle of equal treatment is used as a traditional constitutional benchmark. The prohibition to discriminate will then be understood by reference to the meta-principle of equal treatment, as enshrined in the "standard formula." The explanations on the Charter, for instance, make it clear that Article 20 CFEU_Equality before the law-corresponds to the general principle. ${ }^{55} \mathrm{We}$ will elaborate further on this and explore the role of the concept of "essence" enshrined in Article 52(1) CFEU at the intersection between Charter rights and general principles in Section D. For now, it suffices to stress that among the various expressions of equal treatment examined above there is little doubt that the principle of equal treatment, understood as a mere constitutional benchmark, acts as a default point of reference.

\section{Equal Treatment: A Fundamental Right Given Expression Through Legislation}

Adding to the complexity, a third type of constitutional provisions constitutes a set of legal bases for the adoption of legislation intended to flesh out the fundamental right to equal treatment. Use of them has led to the development of several directives, through which the EU legislature has been able to influence the scope and content of EU intervention on equal treatment. It is necessary to shed light on this third type of constitutional provisions and the related legislation before investigating their influence on the debate on the "essence" of the fundamental right to equal treatment. These legal bases can indeed be understood as allowing for the emergence of a specific "EU fundamental right policy". Contrary to tools discussed in the previous section, these constitutional provisions do not as such have normative content; the focus instead shifts to their offspring. EU legislation giving effect to the prohibition of equal treatment has progressively been understood as "giving expression" to the fundamental right to equal treatment. This has, therefore, influenced the relationship between the said legislation and the fundamental right to equal treatment enshrined in EU constitutional law.

\section{Towards an (Autonomous) Fundamental Right Policy on Equal Treatment}

Although the European Union does not have competence to address fundamental rights violations per se, some branches of EU equality have, over the years, been transformed and, finally expanded to set the floor for an EU sectoral fundamental right policy; in other words, an EU policy devoted to the protection of a specific fundamental right.

The origins of this evolution in relation to the right to equal treatment can be traced back to early case law on the direct effect of what has today become Article 157(1) TFEU. From the 1960s onwards, the story is well known. The Court distinguished the nature of the European project from that of a traditional international legal order. The EU is a unique legal system integrated into those of the Member States, owing to the principles of primacy and direct effect. European law was thus capable of creating rights and obligations for private parties directly. ${ }^{56}$

\footnotetext{
${ }^{55} \mathrm{See}$ CFEU art. 52(7) (stating that the explanations shall be given due regard by the courts of the Union and of the Member States).

${ }^{56}$ See generally Case 26/62, NV Algemene Transport- en Expeditie Orderneming van Gend en Loos v. Netherlands Inland Revenue Administration, 1963 E.C.R. 00001.
} 
This allowed individuals to enforce rules of the EU legal order against their own institutions. The specificity of the EU legal order was taken one step further when the Court, despite the reluctance of the Member States, ${ }^{57}$ asserted in the Defrenne II case that Treaty provisions on equal treatment between men and women in relation to pay-which is now seen in Article 157(1) TFEU-were not only capable of vertical, but also of horizontal direct effect.

Building on this innovative approach to the role of EU law, the Court progressively expanded the possibilities for individuals to rely on the principle of equality as asserted in the Treaty against other individuals, starting from the 1970s and culminating in the late 1990s. Perhaps the clearest example of the transformative function of the principle is to be found in the wording of the Angonese case that related to nationality discrimination. ${ }^{58}$ In that case the Court made it clear that:

Article [45 TFEU] lays down a fundamental freedom and ... constitutes a specific application of the general prohibition of discrimination contained in [Article $18 \mathrm{TFEU}$ ]. In that respect, like Article [157 TFEU], it is designed to ensure that there is no discrimination on the labour market . . . Consequently, the prohibition of discrimination on grounds of nationality laid down in Article [45] of the Treaty must be regarded as applying to private persons as well. ${ }^{59}$

From Defrenne II to Angonese, the Court thus departed from the narrow wording of the Treaty on the prohibition of sex and nationality discrimination as market unifiers and revealed the dormant transformative function of EU equality law; namely that it seeks to achieve equality per se. ${ }^{60}$ This function is now considered to exist alongside the internal market objectives of EU law. ${ }^{61}$

It is common to refer to this judicial transformation of the role of EU equality law as a transition from an economic understanding of the prohibition of discrimination to that of a social approach, or at least to a new approach combining both. ${ }^{62}$ This should not be misunderstood: This transition is about much more than simply setting high standards of social protection at the expense of a deregulatory approach to free trade. This paved the way to address the standards hereby heralded through a fundamental right narrative. ${ }^{63}$ The right would thereby soon be highly moralized. ${ }^{64}$

The prohibitions of sex and nationality discrimination were considered, from the late 1980s, to form part of the "acquis materiel fondamental" of the EU. ${ }^{65}$ As from the Treaty of Amsterdam, a new legislative competence came to life. The new, and current, Article 19 TFEU allows for the adoption of legislation putting flesh on the bones of the right to equal treatment. According to its provisions, the EU legislature may indeed take "appropriate action to combat discrimination

\footnotetext{
${ }^{57}$ See Alec S. Sweet, The Judicial Construction of Europe 45-108, 147-98 (Oxford Univ. Press 2004).

${ }^{58}$ See Case C-281/98, Roman Angonese v. Cassa di Risparmio di Bolzano SpA, 2000 E.C.R. I-4139, paras. 33-36. See also Case 36/74, B.N.O. Walrave \& L.J.N. Koch v. Association Union cycliste international, Koninklijke Nederlandsche Wielren Unie \& Federación Espanola Ciclismo, 1974 E.C.R. 1405, para. 17. See generally Case C-415/93, Union royale belge des sociétés de football association ASBL v. Jean-Marc Bosman \& Others, 1995 E.C.R. I-04921.

${ }^{59}$ Angonese, Case C-281/98 at paras. $35-36$.

${ }^{60}$ See Fritz W. Scharpf, Perpetual Momentum: Directed and Unconstrained?, 19 J. Eur. Pub. Pol'y 127, 132-33 (2012).

${ }^{61} \mathrm{See}$ Case C-50/96, Deutsche Telekom AG v. Lilli Schröder, 2000 E.C.R. I-743, paras. 56-57 (stating that the social function of EU sex equality law is predominant over its internal market function). See also Case C-341/05, Laval un Partneri Ltd v. Svenska Byggnadsarbetareförbundet, Svenska Byggnadsarbetareförbundetsavdelning 1, Byggettan \& Svenska Elektrikerförbundet, 2007 E.C.R. I-11767, para. 105 (stating that the EU internal market policy must be balanced against the objectives pursued by EU social policy).

${ }^{62}$ See generally BELL, supra note 36.

${ }^{63}$ See CFEU, supra note 25, at art. 21.

${ }^{64}$ See Sacha Prechal, Non-Discrimination Does Not Fall Down From Heaven: The Context and Evolution of NonDiscrimination in EU Law 10 (Eric Stein, Working Paper No. 4, 2009) (presenting a thoughtful overview of the evolution of the rationale of EU equality law).

${ }^{65}$ See José L. C. Vilaça \& Nuno Piçarra, Y a-t-il des limites matérielles à la révision des traités instituant les Communautés européenne?, 23 Cahiers de Droit Européen 3, 29 (1993).
} 
based on sex, racial or ethnic origin, religion or belief, disability, age or sexual orientation". Furthermore, what is today Article 157 TFEU would also allow for the adoption of legislation for the "application of the principle of equal opportunities and equal treatment of men and women in matters of employment and occupation, including the principle of equal pay for equal work or work of equal value". ${ }^{66}$ These legal bases stand alone, without the legislator having to prove a link with other-more traditional-battle horses of the EU, such as internal market policy. ${ }^{67}$ In that sense, they set the floor for the first ever legal basis for the adoption of fundamental right legislation in EU law.

This led, in the early 2000s, to the adoption of two new directives and the recasting of EU sex equality legislation. The Racial Equality Directive ${ }^{68}$ prohibits racial or ethnic discrimination in a broad range of settings, from employment and beyond. The Framework Employment Directive ${ }^{69}$ prohibits discrimination on the grounds of religion or belief, disability, age, or sexual orientation in regard to employment and occupation. The Sex Equality Directive ${ }^{70}$ prohibits sex discrimination in employment and occupation. Further instruments were subsequently adopted to update — self-employment ${ }^{71}$ —and broaden—access to goods and services ${ }^{72}$ — the scope of EU sex equality law.

\section{EU Equality Legislation Gives Expression to the Fundamental Right to Equal Treatment}

The fundamental rights dimension of EU equality law and policy has only been fully asserted in recent years. By the early years of the new millennium it had become unquestionable. The Court had long asserted that the right not to be discriminated against on grounds of sex is one of the fundamental human rights whose observance the Court has a duty to ensure. ${ }^{73}$ Yet, it was not until 2000 that the Court went further to assert that Article 157 TFEU on sex equality in employment actually "constitutes the expression of a fundamental human right." ${ }^{74}$ Indeed, in the Deutsche Post cases (2000), the Court set out its reasoning in three stages.

In paragraphs 55, 56, and 57 of the Deutsche Post ruling, the Court moved from an analysis of former Article 119 TEEC—now Article 157(1) TFEU—on sex equality in matters of salary as forming part of the social objectives of the Union; to the reassertion of the right not to be

\footnotetext{
${ }^{66}$ In the past, related legislation had been adopted on the basis of internal market legal bases as well as the flexibility clause.

${ }^{67}$ See also Case C-83/14, CHEZ Razpredelenie Bulgaria' AD v. Komisia za zashtita ot diskriminatsia, paras. 43-44 (July 16, 2015), http://curia.europa.eu/ (showing where the Court referred to provisions of EU law other than those of the Framework Employment Directive to support the finding that the making available to final consumers of individual electricity meters is within the scope of EU law for the purpose of applying that Directive); Piet Eeckhout, The EU Charter of Fundamental Rights and the Federal Question, 39 Common MKT. L. Rev. 945, 986 (2002). See generally Case C-457/17, Heiko Jonny Maniero v. Studienstiftung des deutschen Volkes eV, (Nov. 15, 2018), http://curia.europa.eu/ (illustrating that when interpreting the equality directives, the Court almost never seeks to establish a link between the material scope of the said directives and the material scope of EU law; an exception to this may be found in CHEZ).

${ }^{68}$ See generally Council Directive 2000/43, 2000 O.J. (L 180) (EC) (implementing the principle of equal treatment between persons irrespective of racial or ethnic origin).

${ }^{69}$ See generally Council Directive 2000/78, supra note 8 (establishing a general framework for equal treatment in employment and occupation).

${ }^{70}$ See generally Directive 2006/54, of the European Parliament and of the Council of 5 July 2006 on the Implementation of the Principle of Equal Opportunities and Equal Treatment of Men and Women in Matters of Employment and Occupation, 2006 O.J. (L 204).

${ }^{71}$ See generally Directive 2010/41, of the European Parliament and of the Council of 7 July 2010 on the Application of the Principle of Equal Treatment Between Men and Women Engaged in an Activity in a Self-Employed Capacity and Repealing Council Directive 86/613/EEC, 2010 O.J. (L 180).

${ }^{72}$ See generally Council Directive 2004/113, 2004 O.J. (L 373) (EC) (implementing the principle of equal treatment between men and women in the access to and supply of goods and services).

${ }^{73}$ See Defrenne, Case C-149/77 at paras. 26-27.

${ }^{74}$ Joined Cases C-270/97 \& C-271/97, Deutsche Post AG v. Elisabeth Sievers and Brunhilde Schrage, 2000 E.C.R. I-929, paras. 55-57. See also Deutsche Telekom AG, Case C-50/96 at paras. 55-57.
} 
discriminated against on grounds of sex as one of the fundamental human rights, observance of which the Court has a duty to ensure; and finally to upgrading the social purpose of former Article 119 TEEC on sex equality to be the main purpose of that Article. This final and innovative upgrade has been legitimized by reference to the fact that former Article 119 TEEC constituted the expression of a fundamental human right. The nuance in the wording constitutes more than a linguistic twist: ${ }^{75}$ It illustrates a shift in the perception of this field of law in the late 1990s to the early 2000s towards understanding EU equality law as a fundamental rights "policy," namely a set of policy tools designed to put into effect a fundamental right.

As argued by Koukoulis-Spiliotopoulos, the formula by which former Article 119 TEEC is understood as constituting the expression of a fundamental human right in paragraph 57 of the Deutsche Post ruling applies to any EU gender equality provision. ${ }^{76}$ The Court also applied it to legislation adopted on the basis of Article 19 TFEU in Mangold, ${ }^{77}$ as concerning age discrimination from 2005, as well as more recently in 2018, in relation to religion or belief in Egenberger. ${ }^{78}$ There is no reason why this approach should not also prevail when individuals seek to invoke the other Article 19 TFEU criteria expressed in Directives adopted precisely on the basis of said Article 19 TFEU. $^{79}$ Indeed, Article 19 TFEU mandates the EU legislator to combat discrimination on grounds of sex, racial or ethnic origin, religion or belief, disability, age, or sexual orientation without distinguishing between them.

The timing of both sets of jurisprudential developments on sex equality and the Article 19 TFEU Directives is perhaps no coincidence, occurring in a period when-what is nowArticle 19 TFEU was inserted into the EU Treaties by the Treaty of Amsterdam and the Charter was proclaimed in 2000, before gaining binding force in 2009. ${ }^{80}$ Article 19 TFEU allows for the adoption of legislation covering a fairly wide range of discrimination. Meanwhile Article 21 $\mathrm{CFEU}^{81}$ prohibits any discrimination on the grounds covered by Article 19 TFEU, as well as others, in the field of application of EU law. ${ }^{82}$ Both articles thus suggest that the EU has a much stronger mandate to protect the fundamental right to non-discrimination both at the primary and secondary law levels than it had in the past.

\section{Interim Conclusion: Blurred Boundaries Between Legislative Guidance and the Corresponding Constitutional Right}

It is now clear that EU equality legislation gives expression to the fundamental right to equal treatment. This is true in particular where there is no corresponding constitutional provision performing the dual function of acting as a constitutional benchmark and an EU regulatory tool, referencing Section B above. Legislation, such as that adopted on the basis of Article 19 TFEU, coexists with a constitutional version of the right that cannot, in and of itself, define the scope of EU regulatory intervention because it is only an enabling provision. How then does the existence of legislation influence the definition of the corresponding constitutional right acting as a traditional fundamental rights benchmark, and possibly of the "essence" of that fundamental right? ${ }^{83}$

\footnotetext{
${ }^{75}$ See Sacha Prechal, Equality of Treatment, Non-Discrimination and Social Policy: Achievements in Three Themes, 41 COMMON Mкт. L. Rev. 533, 548 (2004).

${ }^{76}$ See Koukoulis-Spiliotpoulos, supra note 5, at 330.

${ }^{77}$ See Mangold, Case C-144/04 at paras. 74-76.

${ }^{78}$ See Egenberger, Case C-414/16 at para. 47.

${ }^{79}$ See Römer, Case C-147/08 at paras 125-131.

${ }^{80}$ The Amsterdam Treaty also amended what is today TFEU art. 157 to turn it into a legal basis for the adoption of legislation on equal treatment between men and women in employment.

${ }^{81}$ See also CFEU art. 23.

${ }^{82}$ See also TFEU art. 21 (providing for an open-ended list of grounds).

${ }^{83} \mathrm{We}$ are therefore leaving aside the numerous cases that are merely addressed by reference to relevant EU equality legislation. See e.g., Case C-539/15, Daniel Bowman v. Pensionsversicherungsanstalt, para 19 (Dec. 21, 2016), http://curia.europa. eu/; Case C-416/13, Mario Vital Pérez v. Ayuntamiento de Oviedo, para. 25 (Nov. 13, 2014), http://curia.europa.eu/.
} 
One way of answering that question is to look at situations in which the legislative version of the right as well as the provision acting as a constitutional benchmark overlap. This is exemplified by the facts of cases such as Mangold, ${ }^{84}$ Kucükdeveci, ${ }^{85}$ Ajos, ${ }^{86}$ Edenberger, ${ }^{87} \mathrm{IR},{ }^{88}$ or Cresco ${ }^{89}$ In these cases, the situation falls squarely within the scope of application of EU equality directives and the Court has ensured the full enforceability of the content of the relevant equality directive in interpersonal disputes with reference to constitutional manifestations of the right to equal treatment. The Court therefore adopts the "high" and "protective" standards enshrined in EU legislation - for example, the distinction between direct and indirect discrimination, and a partial shift in the burden of proof - to inform the definition of the fundamental right to equal treatment drawn from the general principle and Article $21 \mathrm{CFEU}$ used as a constitutional benchmark. This line of cases has been, and still is, subject to much discussion; it does not, however, to date engage with the question of the "essence" of the fundamental right to equal treatment. In such contexts, the Court has so far relied on legislative guidance to flesh out the right to equal treatment beyond its bare version and without there being any reference to Article 52 CFEU.

A second, more recent and much less discussed trend, concerns to the gap-instead of the overlap just described-between legislation and primary layers of norms. A number of cases reaching the Court indeed relate to the prohibition of discrimination on one of the grounds covered by EU legislation, such as disability, age, or sexual orientation; without however EU legislation giving expression to the fundamental right to equal treatment being applicable. These will be referred to below as "gap cases." How then shall the concept of equal treatment, or its "essence," be defined where legislative guidance exists but is not actually applicable? As we shall see, this has been a delicate matter for the Court to deal with, and the case law remains most unclear.

\section{Articulating Competing Tools for the Protection of Equal Treatment: The Unclear Role of Article 52(1) CFEU and of the Concept of "Essence" Therein}

The analysis of limitations to the fundamental right of equal treatment enshrined in the Charter epitomizes the tension between the various sources thereby mapped out. Article 52(1) CFEU is not relevant to the analysis of restrictions to constitutional provisions performing a dual function as the relevant Treaty provision itself applies. ${ }^{90}$ Article 52(1) CFEU is not relevant either where both equality legislation and constitutional benchmarks jointly apply because the Court has until now relied on the content of the legislation to address the substance of the right to equal treatment. ${ }^{91}$

How then have the general principle of equal treatment, the relevant provisions of the Charter, and the legislation giving expression to the fundamental right interacted for the definition of the core of the principle of equal treatment in the other settings identified above?

In the post-Lisbon era, after the provisions of the CFEU gained the same legal value as the Treaties, ${ }^{92}$ the Charter provided its own road map for the analysis of fundamental rights in its Article 52(1). Article 52(1) CFEU requires inter alia that "any limitation on the exercise of the rights and freedoms recognized by this Charter must . . . respect the essence of those rights and freedoms." Yet, the existence of the general principle predated the Charter and had its own test for the analysis of limitations under the "standard formula" with no mention of the

\footnotetext{
${ }^{84}$ See generally Mangold, Case C-144/04.

${ }^{85}$ See generally Case C-555/07, Seda Kücükdeveci v. Swedex GmbH \& Co. KG., 2010 E.C.R. I-365.

${ }^{86}$ See generally Case C-441/14, Dansk Industri, acting on behalf of Ajos A/S v. Estate of Karsten Eigil Rasmussen, (Apr. 19, 2016), http://curia.europa.eu/.

${ }^{87}$ See generally Egenberger, Case C-414/16.

${ }^{88}$ See generally Case C-68/17, IR v. JQ, (Sep. 11, 2018), http://curia.europa.eu/.

${ }^{89}$ See generally Case C-193/17, Cresco Investigation GmbH v. Markus Achatzi (Jan. 22, 2019), http://curia.europa.eu/.

${ }^{90}$ See supra Section $\mathrm{B}(\mathrm{II})$ and $\mathrm{B}(\mathrm{III})$.

${ }^{91}$ See supra Section C(III).

${ }^{92}$ See generally TFEU art. 6(1).
} 
essence of the right. Simultaneously, in the past decades and as noted above, equality legislation has been fleshing out specific analytical models for claims of discrimination.

It will be observed that the Court has maintained a fairly traditional approach to the principle of equal treatment understood as a constitutional benchmark when no more specific constitutional or legislative provisions were applicable. ${ }^{93}$ The binding nature of new equal treatment provisions enshrined in the Charter that perform the function of mere constitutional benchmarks therefore has not affected the overall approach of the Court in these settings. Instead, the Charter has confirmed the general principle of equal treatment post-Lisbon and the concept of "essence" has been largely ignored.

This contrasts with situations characterized by a more complex relationship with the equal treatment legislation: in the "gap cases". ${ }^{4}$ Here, the interplay between the general principle and the equal treatment clauses enshrined in the Charter has been a source of confusion; in particular due to occasional and inconsistent reliance on Article 52(1) CFEU, as well as the concept of "essence" therein.

\section{Equal Treatment as a Mere Constitutional Benchmark: The Charter Confirms the General Principle of Equal Treatment Post-Lisbon with Little Mention of Article 52(1) CFEU or the Concept of "Essence"}

As noted earlier, but worth further explicating at this stage of the analysis, the Court is familiar with reliance on the principle of equal treatment as a constitutional benchmark. In the post-Lisbon era, the Court has continued operating with it on a regular basis, relying on its standard formula, and simply often-although not always ${ }^{95}$ - adding references to equal treatment provisions of the Charter.

\section{References to the Constitutional Principle Pre-Lisbon: The General Principle}

One of the most elaborate analyses of the general principle of equal treatment in the period just preceding the Lisbon Treaty's entry into force can be found in the Arcelor case. ${ }^{96}$ The Court was asked whether Directive 2003/87-establishing a scheme for greenhouse gas emission allowance trading within the Community - was compatible with the principle of equal treatment, in so far as it makes the allowance trading scheme applicable to installations in the steel sector without including in its scope the aluminum and plastics industries. The case, as well as all those discussed in this section, ${ }^{97}$

\footnotetext{
${ }^{93}$ As explained supra in Section B(III), where more specific constitutional provisions performing a dual function apply, they shall be relied upon and CFEU art. 52(1) will not be relevant.

${ }^{94}$ As explained supra in Section C(III), the "overlap cases," whereby both legislation and constitutional benchmarks jointly apply, are characterized by reliance on the content of the legislation to address the substance of the matter; CFEU art. 52(1) is therefore not relevant.

${ }^{95}$ See Case C-112/16, Persidera SpA v. Autorità per le Garanzie nelle Comunicazioni, Ministero dello Sviluppo Economico delle Infrastrutture e dei Trasporti, paras. 46-55 (Mar. 30, 2017), http://curia.europa.eu/. See also Case C-38/16, Compass Contract Services Limited v. Commissioners for Her Majesty's Revenue and Customs, para. 24. (June 14, 2017), http:// curia.europa.eu/; Case C-560/15, Europa Way Srl, Persidera SpA v. Autorità per le Garanzie nelle Comunicazioni, Ministero dello Sviluppo economico, Presidenza del Consiglio dei Ministri, Ministero dell'Economia e delle Finanze, para. 69 (July 26, 2017), http://curia.europa.eu/; Case C-286/12, Hungary v. Commission, paras. $73-45$ (Nov. 6 2012), http:// curia.europa.eu/; Case C-50/12, Kendrion NV v. Commission, paras. 60-68 (Nov. 26, 2013), http://curia.europa.eu/; Case C-176/09, Grand Duchy of Luxembourg v. European Parliament, 2011 E.C.R. I-3755, para. 31; Case C-496/08, Pilar Angé Serrano et al. v. European Parliament, paras. 100-08 (Mar. 4, 2010), http://curia.europa.eu/; Case T-704/14, Marine Harvest ASA v. European Commission, paras. 207-08 (Oct. 26, 2017), http://curia.europa.eu/; Case T-424/13, Jinan Meide Casting Co. Ltd v. Council of the European Union, paras. 156-58 (June 30, 2016), http://curia.europa.eu/; Case T-260/11, Kingdom of Spain v. European Commission, paras. 93-99 (June 18, 2014), http://curia.europa.eu/.

${ }^{96}$ See generally Case C-127/07, Société Arcelor Atlantique et Lorraine and Others v. Premier ministre, Ministre d l'Écologie et du Développement durable, Ministre de l'Économie, des Finances et de l’Industrie, 2008 E.C.R. I-9895.

${ }^{97}$ Section $\mathrm{D}(\mathrm{I})$.
} 
was neither covered by EU equality legislation nor by any of the constitutional provisions performing a dual function. Instead, the principle of equal treatment acted as a classic constitutional benchmark.

It is useful to spell out the reasoning of the Court for reference. It aptly illustrates the Court's traditional approach in such cases. In Arcelor, the Court started by recalling its "standard formula": "The general principle of equal treatment, as a general principle of Community law, requires that comparable situations must not be treated differently and different situations must not be treated in the same way unless such treatment is objectively justified." ${ }^{\prime 8}$

The Court further asserted that the application of the principle of equal treatment requires first a finding that "the situations concerned are comparable, having regard to all the elements which characterize them." ${ }^{\prime 9}$ The Court also provided guidance on comparability:

The elements which characterize different situations, and hence their comparability, must in particular be determined and assessed in the light of the subject-matter and purpose of the Community act which makes the distinction in question. The principles and objectives of the field to which the act relates must also be taken into account . . . 100

The Court found the existence of comparable situations and differential treatment, but the latter was justified.

\section{References to the Constitutional Principle Post-Lisbon: The General Principle and Articles 20-21 CFEU}

In cases that followed the entry into force of the Lisbon Treaty, the principle of equal treatment has quite naturally continued to perform its function as a classic constitutional benchmark. Importantly, the Court does not seem to have adjusted its methodological approach other than selectively ${ }^{101}$ adding references to the equal treatment provisions enshrined in the Charter. Selected examples below aptly illustrate this approach.

In $A k z o$ Nobel, ${ }^{102}$ the parties submitted that the interpretation of one of the conditions for legal professional privilege-which concerns the professional status of the lawyer with whom communications are exchanged-by the General Court breached the principle of equality. The Court stated that "the principle of equal treatment is a general principle of European Union law, enshrined in Articles 20 and 21 of the Charter," and further reiterated the standard formula on the definition of the principle of equal treatment. ${ }^{103}$ In Vervloet, ${ }^{104}$ the referring court asked whether Articles 2 and 3 of Directive 94/19, on deposit guarantee schemes, read in conjunction with Articles 20 and 21 of the Charter and the general principle of equal treatment must be interpreted as requiring Member States to adopt a scheme to guarantee the shares of recognized cooperatives operating in the financial sector. The Court also made a joint reference to the general principle, and Articles 20 and 21 of the Charter. ${ }^{105}$ In both cases, there was no further reference to Article 52(1) CFEU. It shall be noted, however, that in these cases, the Court stopped the

\footnotetext{
${ }^{98}$ Société Arcelor Atlantique et Lorraine, Case C-127/07 at para. 23.

${ }^{99} \mathrm{Id}$. at para. 25.

${ }^{100} I d$. at para. 26.

${ }^{101}$ See Case T-793/14, Tempus Energy Ltd. \& Tempus Energy Technology Ltd. v. European Commission, para. 164 (Nov. 15, 2018), http://curia.europa.eu/ (outlining a recent example of a ruling where reference is made to the general principle of equal treatment but not to the related provisions of the Charter).

${ }^{102}$ See generally Case C-550/07, Akzo Nobel Chemicals Ltd. \& Akcros Chemicals Ltd. v. European Commission, 2010 E.C.R. I-8301.

${ }^{103}$ Akzo Nobel Chemicals Ltd., Case C-550/07 at paras. 54-55.

${ }^{104}$ See generally Case C-76/15, Paul Vervloet and Others v. Ministerraad (Dec. 21, 2016), http://curia.europa.eu/.

${ }^{105} I d$. at para. 74 .
} 
analysis at the stage of comparability; there was thus, in any case, no need to further reflect on the limits to equal treatment. ${ }^{106}$

In other cases, the Court needed to elaborate on the analysis of differential treatment. Yet, once again, there was no mention of Article 52(1) CFEU. ${ }^{107}$ In Schaible, ${ }^{108}$ for instance, the national court entertained doubts as to the compatibility of Regulation 21/2004 - establishing a system for the identification and registration of ovine and caprine animals - with higherranking EU law. The Court asserted that "[e]quality before the law, set out in Article 20 of the Charter, is a general principle of European Union law," and followed up with the standard formula. ${ }^{109}$ A detailed analysis of the compatibility of the regulation with the principle of equal treatment ensued, including examination of justification and proportionality, but with no further reference to the Charter. ${ }^{110}$ In Szatmari Malomi, ${ }^{111}$ the question related to whether Regulation 1698/2005-concerning support for rural development by the European Agricultural Fund for Rural Development-empowered the national legislature to exclude certain types of development from support for economic reasons. The Court followed a similar approach referring to "general principles of [EU law], such as the principle of equal treatment enshrined in Article 20 of the Charter." "12 The Court then called for the national court to make a final decision on the comparability of the different situations under scrutiny; yet, the Court also noted that there may be a breach of the principle of equal treatment in the situation at hand. This last remark was made by mere reference to the principle of equal treatment, without further reference to other provisions of the Charter. ${ }^{113}$

\section{Conclusions: The General Principle Remains the Standard Analytical Tool}

As things currently stand, ${ }^{114}$ the case law on the principle of equal treatment acting as a constitutional benchmark calls for two remarks. First, the Court does not rigorously distinguish between Articles 20 and 21 CFEU. Both are understood as expressions of the general principle of equal treatment.

Second, references to the Charter are only made to support a traditional and long-established approach to the analysis of allegations of breach of the general principle of equal treatment. Not only does the definition of the principle remains unchanged, but also, and more importantly for our purpose, the examination of limitations to the principle is performed by reference to the standard formula with no mention of Article $52 \mathrm{CFEU}$ - and therefore no mention of the essence of the said fundamental right.

\footnotetext{
${ }^{106}$ See Akzo Nobel Chemicals Ltd., Case C-550/07 at para. 58. See also Paul Vervloet, Case C-76/15 at para. 75.

${ }^{107}$ See Case C-390/15, Rzecznik Praw Obywatelskich (RPO) v. Marszałek Sejmu Rzeczypospolitej Polskiej, Prokurator Generalny, paras. 38-41 (Mar. 7, 2017), http://curia.europa.eu/. See also Case C-156/15, 'Private Equity Insurance Group” SIA v. "Swedbank" AS, 2016 E.C.R., paras. 49-53 (Nov. 10, 2016), http://curia.europa.eu/; Case C-110/15, Microsoft Mobile Sales International Oy v. Ministero per i beni e le attivita culturali (MiBAC) and Others, paras. 44-50 (Sep. 22, 2016), http://curia.europa.eu/; Case C-463/12, Copydan Båndkopi v. Nokia Danmark A/S, paras. 31-41 (Mar. 5, 2015), http://curia.europa.eu/; Chatzi, Case C-149/10 at paras. 63-75; Case C-21/10, Károly Nagy v. Mezőgazdasági és Vidékfejlesztési Hivatal, 2011 E.C.R. I-6769, paras. 47-50.

${ }^{108}$ See generally Case C-101/12, Herbert Schaible v. Land Baden-Württemberg (Oct. 17, 2013), http://curia.europa.eu/.

${ }^{109} \mathrm{Id}$. at para. 76.

${ }^{110}$ See id. at para. 27 (showing that this is all the more remarkable in this case as the Court did refer to CFEU art. 52(1) in the analysis of limitations to the other fundamental right invoked, being the freedom to conduct a business). See also Case C-534/16, Finančné riaditelstvo Slovenskej republiky v. BB construct s.r.o., paras. 30, 47 (Oct. 26, 2017), http://curia.europa.eu/ (contrasting with para. 43).

${ }^{111}$ See generally Case C-135/13, Szatmári Malom Kft. v. Mezőgazdasági és Vidékfejlesztési Hivatal Központi Szerve, (May 15, 2014), http://curia.europa.eu/.

${ }^{112} I d$. at para. 65.

${ }^{113} I d$. at para. 69.

${ }^{114}$ The search method is spelled out in the Annex.
} 
A noticeable exception to this observation emerges from the very recent ruling in Spika. ${ }^{115}$ There, the Court equated Article $20 \mathrm{CFEU}$ and the general principle of equal treatment as follows:

Article 20 of the Charter ... enshrines the general principle of EU law of equal treatment, which requires that comparable situations must not be treated differently and different situations must not be treated in the same way unless such treatment is objectively justified. ${ }^{116}$

The Court then moved on to examine whether the conditions enshrined in Article 52(1) CFEU were fulfilled to tolerate a limitation of Article 20 CFEU. ${ }^{117}$ This includes an analysis of the effect of the restriction on the essence of the right to equal treatment enshrined in Article $20 \mathrm{CFEU}$ :

The Law on Fisheries does not have the effect of calling into question the principle of equal treatment, and provides in particular, in Article $17^{1}(4)$, for the possibility of taking into account specific situations in which operators may find themselves. Therefore, that method respects also the essence of the rights that the different types of operators derive from Article 20 of the Charter. ${ }^{118}$

The Court finally further analyzed justifications and proportionality. ${ }^{119}$

It is too early to say whether this ruling from the Fifth Chamber of the Court is indicative of a new approach or merely a coincidence. Importantly, the limitation to the right to equal treatment in Article $20 \mathrm{CFEU}$ was examined in parallel to a limitation to the fundamental right to conduct a business in Article $16 \mathrm{CFEU}$; this may have induced the Court to structure its reasoning by reference to Article 52(1) CFEU in relation to both fundamental rights. ${ }^{120}$ It is remarkable that the Court $^{121}$ not only referred to Article 52(1) CFEU, but also discussed the "essence" of the fundamental right to equal treatment; although little can be inferred from the Court's statement on this point. $^{122}$

\section{Equal Treatment as a Constitutional Benchmark Coexisting with Inapplicable Equal Treatment Legislation: In Search for Guidance in the Charter}

A distinct set of examples relates to the principle of equal treatment on one of the grounds protected by EU equality legislation and falling within the scope of EU law, but without being regulated by the said equality legislation. Examples of such "gap cases" include claims of sexual orientation against domestic measures that do not relate to employment and thus are not covered

\footnotetext{
${ }^{115}$ See generally Case C-540/16, "Spika" UAB, "Senoji Baltija” AB, "Stekutis” UAB, "Prekybos namai Aistra” UAB v. Žuvininkystès tarnyba prie Lietuvos Respublikos žemès ūkio ministerijos (July 12, 2018), http://curia.europa.eu/.

${ }^{116} I d$. at para. 35 .

${ }^{117}$ See id. at para. 36.

${ }^{118} \mathrm{Id}$. at para 39.

${ }^{119}$ See id. at paras. $40-56$.

${ }^{120}$ See id. at paras. $38-40$.

${ }^{121}$ See infra Section D (II)(2) and the discussion on Milkova.

${ }^{122}$ See "Spika" UAB, Case C-540/16 at para. 9:

Under Article 171(4) of [the law under examination], the individual fishing opportunities allocated to an operator are equal to the historical share, which may be reduced or increased in accordance with the following criteria: The historical share shall be increased by $0.1 \%$ for each share, in percentage terms, in the fishery products of the species concerned sold in the territory of the Republic of Lithuania, determined on the basis of all the fishery products of that species caught by the operator during the reference years; in order to take into account the lesser effects of an operator's commercial fishing on the environment, the historical share shall be increased by $5 \%$ when selective commercial fishing gear and fishing techniques that preserve natural habitats are used, and by $5 \%$ for fishing vessels which pollute the environment less and use less energy; the historical share shall be reduced by $2 \%$ for each serious infringement committed during the reference years and by $0.5 \%$ for each infringement of the rules governing commercial fishing that was not considered serious.
} 
by the Framework Employment Directive as in Léger; or claims related to the special treatment of disabled persons at a domestic level that go beyond the requirements of the Framework Employment Directive as in Milkova. Alternatively, claims of disability, sex, or age discrimination may be targeted against EU legal acts and therefore fall outside the scope of EU equality legislation, which is addressed to the Member States as in Glatzel, Fries, and Test-Achats - also discussed in this section.

The Court is then called upon to interpret the general principle of equal treatment, Article 20 CFEU or Article $21 \mathrm{CFEU}$, that prohibits discrimination on one of the grounds covered by EU legislation giving flesh to the fundamental right, but without being bound by the specific legislative framework provided for discrimination on grounds of sexual orientation, disability, age, or sex. ${ }^{123}$ In these "gap cases," possibly because the Court feels awkward applying the prohibition of discrimination without being able to rely on related equality legislation, it has thought to anchor its reasoning more strongly in the wording of the Charter. It, however, does not make a consistent use of Article 52(1) CFEU and the concept of "essence" contained therein; nor does it even refer to Article 52(1) CFEU in all cases.

\section{Unclear Reliance on Article 52 CFEU and the Concept of "Essence" for the Analysis of Limitations to the Fundamental Right to Equal Treatment}

The three cases examined below each illustrate different approaches.

\subsection{The General Principle Matched with Article 52(1) CFEU: Glatzel}

In Glatzel, the Court was asked to examine whether the EU rules laying down requirements for visual acuity for the drivers of power-driven vehicles in categories $\mathrm{C} 1$ and $\mathrm{C} 1 \mathrm{E}$ are contrary to Article 21(1) of the Charter, including the prohibition of discrimination on grounds of disability. The Court started by noting that limitations on the exercise of the rights recognized in the Charter must be analyzed through the lens of Article 52(1) CFEU. ${ }^{124}$ After having recalled the substance of Article 52(1) CFEU, the Court stated at paragraph 43:

The principle of equal treatment is a general principle of EU law, enshrined in Article 20 of the Charter, of which the principle of non-discrimination laid down in Article 21(1) of the Charter is a particular expression. According to settled case-law, that principle requires the EU legislature to ensure, in accordance with Article 52(1) of the Charter, that comparable situations must not be treated differently and that different situations must not be treated in the same way unless such treatment is objectively justified . . . ${ }^{125}$

What is remarkable about this approach is twofold. First, the general principle is confirmed by reference to Articles 20 and $21 \mathrm{CFEU}$, as in the cases examined above. Second, and more importantly, the standard definition of the general principle of equal treatment is immediately related to Article 52(1) CFEU [see emphasis added]. Yet, it is not clear how precisely the respective mechanics of the general principle and those of Article 52(1) CFEU relate to one another.

The Court does not, however, further refer to Article 52(1) CFEU. It instead articulates its analysis of differential treatment by reference to Article 21(1) $\mathrm{CFEU}^{126}$ and proceeds with the traditional construction of the principle of equal treatment. The Court explicitly draws inspiration from its case law in the context of the Framework Employment Directive, related to disability

\footnotetext{
${ }^{123} \mathrm{CFEU}$ art. 20 has so far been little used in such a context. See Case C-356/12, Wolfgang Glatzel v. Freistaat Bayern, paras. 80-86. (May 22, 2014), http://curia.europa.eu/ (cross-referencing the general principle of equal treatment in paras. 81 and 43 ). See also Léger, Case C-528/13 at para. 48.

${ }^{124}$ See Glatzel, Case C-356/12 at para. 42.

${ }^{125}$ See Glatzel, Case C-356/12 at para. 43.

${ }^{126}$ See Glatzel, Case C-356/12 at para. 49.
} 
discrimination in employment, to define the notion of disability and to explain its approach to justifications for differential treatment. ${ }^{127}$ The Court also refers to EU sex equality case law for the analysis of proportionality. ${ }^{128}$

The tying of the general principle of equal treatment with Article 52(1) CFEU at paragraph 43 of Glatzel could suggest that the general principle-defined with reference to the standard formula - is the essence of the fundamental right to equal treatment. Yet, this approach is not supported by specific aspects of the ruling, and the wording of paragraph 43 has not been repeated in any of the subsequent cases to date. In any case, such an approach would be incompatible with the absolute view on the concept of "essence," as the standard formula requires balancing between competing interests instead of the integral protection of a part of the right.

\subsection{The General Principle Pushed to the Back Stage: Léger}

In Léger, the Court examined the criterion for permanent deferral from blood donation referred to in EU law. That criterion was defined with reference to sexual behavior which places a person at risk of acquiring severe infectious diseases that can be transmitted by blood. The referring court asked whether a Member State must be precluded from reading the said criterion as requiring a permanent contraindication to blood donation for men who have had sexual relations with other men. The Court relied on "Article 21(1) [as] a particular expression of the principle of equal treatment, which is a general principle of EU law enshrined in Article 20 of the Charter," in order to check whether the implementation of EU law excluding homosexuals from blood donation was in conformity with fundamental rights. ${ }^{129}$ The Charter thus confirmed the general principle once again.

In contrast with Glatzel, though, the Court hardly referred to concepts developed in the context of the Framework Equality Directive on sexual orientation discrimination in employment or equality law more broadly. Nor did it refer any further to the general principle of equal treatment.

Instead, the Court heavily relied on Article 52(1) CFEU, which spells out a general scheme for the analysis of limitations to the exercise of rights and freedoms recognized by the Charter. ${ }^{130}$ Relying on the specific requirements of Article 52(1) CFEU, the Court emphasized the need for such limitations to be provided for by law and to respect the essential contents of the principle of non-discrimination. ${ }^{131}$

The fundamental right to equal treatment was thereby somewhat removed from its link with anti-discrimination law, ${ }^{132}$ and, instead, dealt with in accordance with standard fundamental rights methodology. This provided the first opportunity for the Court to make use of the concept of "essence" in the context of an equal treatment claim. On this point, the Court briefly stated "that limitation respects the essential contents of the principle of non-discrimination. That limitation does not call into question the principle as such, as it concerns only the question, which is limited in scope, of deferrals from blood donation in order to protect the health of the recipients." 133

In other words, the Court did not provide a definition of the concept of "essence"; it instead asserted that there was no encroachment on the said concept. The test performed, in a single

\footnotetext{
${ }^{127}$ See Glatzel, Case C-356/12 at paras. 45-46, 49-51.

${ }^{128}$ See Glatzel, Case C-356/12 at para. 56.

${ }^{129}$ Léger, Case C-528/13 at para. 48.

${ }^{130}$ See id. at paras. $51-55,68$.

${ }^{131}$ See id. at paras. $53-54$.

${ }^{132}$ Compare Koen Lenaerts \& Eddy de Smijter, A "Bill of Rights" for the European Union, 38 CommON MKT. L. REv. 273, 284-85 (2001), with Country Report Non-discrimination: France, at 111, European Commission (2015), http://www. equalitylaw.eu/downloads/3707-2015-fr-country-report-ln-final (regarding the Baby Loup saga in France where the Social Chamber of the Cour de Cassation (Soc. Cass, $\mathrm{N}^{\circ} 11-28845$, Mar. 19, 2013) took-primarily-an anti-discrimination approach in order to find a violation of the prohibition of discrimination, whereas the Assemblée plenière of the Cour de Cassation (Ass. Cass, $\mathrm{N}^{\circ} 13-28369$, June 25,2014$)$ in the same case took a legitimate restriction to rights and freedom approach concluding that there was no breach).

${ }^{133}$ Léger, Case C-528/13 at para. 54.
} 
sentence, provides little guidance on what the Court understands by the essence of the principle of equal treatment. The Court seems to be only preoccupied by the scope of the discrimination, which seems an ill-suited tool to explore the essence of a right.

\subsection{The General Principle and Equal Treatment in the Charter Operate at Different Stages of the Reasoning: Fries}

The ruling in Fries ${ }^{134}$ involved an indirect challenge to Annex I of Regulation 1178/2011 - laying down technical requirements and administrative procedures related to civil aviation aircrew-for breach of Article 21(1) CFEU due to age discrimination.

The Court's analysis stands in between the two approaches introduced above. The Court relied on EU primary law in similar, yet more focused, terms as in Glatzel and Léger: "The principle of equal treatment is a general principle of EU law, enshrined in Article 20 of the Charter, of which the principle of non-discrimination laid down in Article 21(1) of the Charter is a particular expression." 135

As in Glatzel, the Court also heavily relied on earlier equality case law, starting with a full definition of the principle of equal treatment in accordance with the standard formula. ${ }^{136}$

The Court then swiftly asserted the existence of a difference of treatment, but did not further rely on traditional equal treatment methodology. ${ }^{137}$ Instead, for the examination of the limitations to the right to equal treatment, as in Léger, the Court applied the analytical scheme provided for in Article 52(1) CFEU. The principle of equal treatment enshrined in Article 21(1) CFEU and Article 52(1) CFEU was articulated as follows: "It must be examined. . whether that difference in treatment is nevertheless compatible with Article 21(1) of the Charter in that it satisfies the criteria set out in Article 52(1) thereof." 138 It is remarkable that there is no mention of the standard formula at this stage.

The Court then relied heavily on the specificities of Article 52(1) CFEU. It paid particular attention to the fact that limitations were provided for by law and did not call into question the principle of equal treatment as such—and therefore its "essence." To that effect, the Court insisted, as in Léger, on the narrow scope of the limitation to the fundamental right. ${ }^{139}$ The Court then continued to reason within the framework of Article 52(1) CFEU in order to check if the limitations to the fundamental right were justified and proportionate. Nevertheless, this examination of the conditions set out in Article 52(1) CFEU was performed by relying on established case law on the principle of equal treatment. ${ }^{140}$

The ruling in Fries is therefore conceptually confusing. It seems to go back and forth from the general principle of equal treatment and Article 21(1) CFEU, on the one hand, to Article 52(1) CFEU and general fundamental rights methodology, on the other hand, without clearly distinguishing between the two. This can interestingly be contrasted with a different set of cases where Article 52(1) CFEU has simply not been mentioned, as we shall now see.

\section{Article 52 CFEU May Not be Mentioned in the Analysis of Limitations to the Fundamental Right to Equal Treatment}

Interestingly indeed, in certain "gap cases," the Court relies on the equal treatment provisions of the Charter but does not refer to Article 52 CFEU. The Court unfolds an equal treatment reasoning on the basis of Charter provisions but without there being need to rely on Article 52 CFEU.

\footnotetext{
${ }^{134}$ See generally Case C-190/16, Fries v. Lufthansa City Line GmbH, (July 5, 2017), http://curia.europa.eu/.

${ }^{135} \mathrm{Id}$. at para. 29.

${ }^{136}$ See id. at para. 30 .

${ }^{137}$ See id. at para. 34 .

${ }^{138} \mathrm{Id}$. at para. 35 .

${ }^{139}$ See id. at para. 38 .

${ }^{140}$ See id. at paras. $39-69$.
} 


\subsection{Exclusive Reliance on Equal Treatment Provisions in the Charter: Test-Achats}

The Test-Achats ${ }^{141}$ case is well known as it constituted a fairly spectacular clash between the judiciary and political institutions on how to articulate the fundamental right to equal treatment. The Court invalidated a derogatory regime built into the Directive implementing the principle of equal treatment between men and women in the access to, and supply of, goods and services. Because a Directive on equal treatment was tested against the fundamental right to equal treatment, the analysis had to be performed against the constitutional version of the right. The Court and the legislature disagreed on how to articulate equal treatment in this context.

What is interesting is the way the Court structures its analysis of the constitutional version of equal treatment between men and women. The Court primarily relies on Articles 21 and 23 CFEU, ${ }^{142}$ with reference to a series of provisions of the TFEU illustrating the importance of sex equality in EU law. ${ }^{143}$ The Court also relies on the standard formula without making an explicit link with the general principle of EU law. ${ }^{144}$

The Court's choice to anchor its reasoning in the equal treatment provisions of the Charter, by contrast to the general principle of equal treatment, may be explained by the strong interinstitutional dimension of the dispute: The Court sought support in the wording of the Charter to back up its disagreement with the legislator. The unfolding of the equal treatment reasoning in that case is then of little importance as the Court primarily focuses on the lack of internal consistency of the legislative instrument ${ }^{145}$ and swiftly concludes it lacks proportionality. ${ }^{146}$ There was no reference to Article 52(1) CFEU, as well as only a concise reference to the standard formula.

\subsection{The General Principle Informs the Content of Article 21 CFEU: Milkova}

The ruling in Milkova was, yet again, different. The matter related to domestic rules intended to reduce actual instances of inequality affecting people with disabilities as allowed for by Article 7(2) of the Framework Equality Directive. The Court considered that, where EU legislation allows Member States a choice between various methods of implementation, the Member States must exercise their discretion in accordance with general principles of EU law, including the principle of equal treatment. ${ }^{147}$ The domestic rule at hand conferred on employees with certain disabilities specific advanced protection in the event of dismissal, without conferring such protection on civil servants with the same disabilities. The Court was asked to assess this situation in light of the principle of equal treatment.

The Court framed its analysis in a slightly different way than in other rulings:

The principle of equal treatment is a general principle of EU law, now enshrined in Articles 20 and 21 of the Charter, which requires that comparable situations must not be treated differently and that different situations must not be treated in the same way unless such treatment is objectively justified. ${ }^{148}$

\footnotetext{
${ }^{141}$ See generally Case C-236/09, Association Belge des Consommateurs Test-Achats ASBL and Others v. Conseil des ministers, 2011 E.C.R. I-773.

${ }^{142}$ See id. at paras. $17,32$.

${ }^{143}$ See id. at paras. $18-20$.

${ }^{144}$ See $i d$. at para. 28.

${ }^{145}$ See generally Lenaerts, supra note 90 (explaining the Court's approach in his own terms).

${ }^{146}$ See Association Belge des Consommateurs Test-Achats ASBL, Case C-236/09 at paras. 31-32.

${ }^{147}$ See Case C-406/15, Petya Milkova v. Izpalnitelen direktor na Agentsiata za privatizatsia i sledprivatizatsionen kontrol, paras. 52-53 (Mar. 9, 2017), http://curia.europa.eu/.

${ }^{148} I d$. at para. 55.
} 
Unlike in the other cases, the Court merges the general principle-defined with reference to the standard formula-with Articles 20 and 21 CFEU. This is to be welcomed, as it avoids any confusion on the relationship between these various tools and ensures coherence. ${ }^{149}$

The Court then unfolds its equal treatment reasoning by reference to the traditional approach in equal treatment cases: Comparability, ${ }^{150}$ differential treatment, and justifications with deference to the domestic court. ${ }^{151}$ No reference is made to Article 52(1) TFEU, and the Court concludes with an interpretation of "the general principle of equal treatment enshrined in Article 20 and 21 of the Charter," 152 so as to confirm the unicity of the conceptual framework behind these provisions.

This approach is remarkable for the clarity of the framework relied upon as well as the consistency with earlier equal treatment cases, to which several references are made. The ruling provides little guidance as to the relationship between the general principle and Articles 20-21 CFEU, on the one hand, and Article 52(1) CFEU, on the other, if only to suggest that Article 52(1) CFEU may not be relevant, or only redundant, for an analysis of the fundamental right to equal treatment.

\section{E. Conclusion: The Principle of Equal Treatment has Long Been Essentialized}

The case law on equal treatment post-Lisbon suggests that the analysis of restrictions to the fundamental right to equal treatment has not changed, with little references to Article 52(1) CFEU. This is particularly clear where the principle acts as a classic constitutional benchmark and the Charter is only used to confirm the principle. The analysis of the "gap cases" also reveals that the underlying logic of the general principle of equal treatment encapsulated in the standard formula remains largely untouched. In cases such as Glatzel, Fries, and Milkova, although the approaches differ, the dynamics of traditional equal treatment analysis remain very present.

What is remarkable about the "gap cases," however, is the high degree of confusion on the methodology to analyze limitations to equal treatment claims grounded in EU constitutional law. While heavy reliance on the Charter to support the analysis of claims that are closely related-yet not covered-by equality legislation is understandable, the current case law lacks consistency.

Admittedly, this lack of consistency has so far not had practical implications. One source of concern, though, is the ambiguous use of the concept of "essence" of the fundamental right by reference to the limited scope of the restriction of equal treatment in Léger, as well as in Fries. Reliance on the concept of "essence" by reference to the scope of the restriction has the paradoxical effect of actually undermining the very idea behind equal treatment. It suggests that discriminations limited in scope cannot call into question the essence of the principle: That would be at odds with the very purpose of the principle of equal treatment and would call into question its very foundation. The principle of equal treatment is grounded in dignitarian arguments; that is in dignity as a value, a quality - by contrast to a quantity. ${ }^{153}$ It is difficult to reconcile this dignitarian underpinning with the idea, put forward in these rulings, according to which restrictions that are limited in scope are for that very reason excluded from the risk of calling into question the foundations of the right to equal treatment. Instead, the scope of the restriction to equal treatment can only be part of the proportionality test under the "standard formula," which is downstream from a traditional equal treatment analysis.

\footnotetext{
${ }^{149}$ The same approach was followed more recently in Spika, as discussed supra in Section D (I).

${ }^{150}$ See Milkova, Case C-406/15 at paras. 56-60.

${ }^{151}$ See id. at paras. $61-63$.

${ }^{152} I d$. at para. 64.

${ }^{153}$ See Opinion of Advocate General Maduro, Case C-303/06, S. Coleman v. Attridge Law \& Steve Law, 2008 E.C.R. I-5603, paras. $8-14$.
} 
It is submitted that an appropriate analytical approach would be to treat the "standard formula" as the test for the analysis of limitations to the principle of equal treatment as proposed in the Milkova case, as well as in the cases where the principle acts as a traditional constitutional benchmark. The "standard formula" results from a long and well-established line of cases defining the general principle of equal treatment, which Articles 20, 21 and 23 CFEU only confirms. In other words, the principle of equal treatment has for a long time been central to the process of European integration and its bare expression encapsulated in the "standard formula" presupposes the possibility of balancing competing interests. 